\title{
Evidence on prevention of skin lesions in newborns: integrative review
}

Evidências sobre prevenção de lesões de pele em recém-nascidos: revisão integrativa

Evidencia sobre prevención de lesiones cutáneas en recién nacidos: revisión integradora

Simone Vidal Santos*, Flávia Regina Souza Ramos², Roberta Costa², Luís Manuel da Cunha Batalha

ORCID IDS

Santos SV (D) https://orcid.org/0000-0002-5086-6326

Ramos FRS (D) https://orcid.org/0000-0002-0077-2292

Costa R (iD https://orcid.org/0000-0001-6816-2047

Batalha LMC (D) https://orcid.org/0000-0002-5328-1470

\section{HOW TO CITE}

Santos SV; Ramos FRS; Costa R; Batalha LMC (2019) Evidence on prevention of skin lesions in newborns: integrative review. ESTIMA, Braz. J. Enterostomal Ther., 17: e2219. https://doi.org/10.30886/ estima.v17.787_IN

Taken from the doctoral thesis entitled: Neonatal Skin Safe®: Mobile application to support the decision of nurses in the prevention of skin lesions in hospitalized newborns. Graduate Program in Nursing, Universidade Federal de Santa Catarina, 2019.

\begin{abstract}
Objective: To identify strategies for the prevention of skin lesions in hospitalized newborns (NBs), published in scientific journals from 2013 to 2018. Method: Integrative literature review performed in two moments of database search, selecting 37 studies published between 2013 and 2018. Results: Thermoregulation, use of antiseptic, use of emollients and cleaning of the umbilical stump were the most commonly found recommendations. Among the evidence-based practices, we highlight those that prevent the risk of hypothermia, such as the use of a polyethylene bag and skin-to-skin contact, which support the assistance and ensure safety in the care of the neonatal patient. Conclusion: The prevention of skin lesions is a relevant topic. However, there is a scarcity of robust evidence to safely sustain NB care practices. It is also observed that the evidence is insufficient to encompass the universe of the theme, demonstrating that skin care is a theme that requires investment and more research.
\end{abstract}

KEYWORDS: Nursing care; Skin; Infant, Newborn; Enterostomal therapy; Evidence-based nursing.

1 Universidade Federal de Santa Catarina - Hospital Universitário Professor Polydoro Ernani de São Thiago - Florianópolis/SC - Brasil. 2Universidade Federal de Santa Catarina - Programa de Pós-Graduação em Enfermagem - Florianópolis/SC - Brasil.

${ }^{3}$ Escola Superior de Enfermagem de Coimbra - Coimbra - Portugal.

Correspondence author: Simone Vidal Santos, E-mail: simonevidal75@gmail.com

Received: Jul. 16, 2019 | Accepted: Oct. 23, 2019 


\section{RESUMO}

Objetivo: identificar estratégias para a prevenção de lesões de pele em recém-nascidos (RN) hospitalizados, publicadas em periódicos científicos no período de 2013 a 2018. Método: revisão integrativa de literatura realizada em dois momentos de busca em bases de dados, sendo selecionados 37 estudos publicados entre os anos de 2013 e 2018. Resultados: termorregulação, uso de antisséptico, uso de emolientes e limpeza do coto umbilical foram as recomendações mais encontradas. Entre as práticas baseadas em evidência, destacam-se as que previnem o risco de hipotermia, como o uso de saco de polietileno e o contato pele a pele, que respaldam a assistência e que garantem segurança no cuidado do paciente neonatal. Conclusão: a prevenção de lesões de pele é um tema relevante, entretanto, existe escassez de evidências robustas para sustentar, com segurança, as práticas de cuidados com o RN. Observa-se ainda que as evidências são insuficientes para englobar o universo do tema, demonstrando que o cuidado com a pele é um tema que demanda investimentos e mais pesquisas.

DESCRITORES: Cuidados de Enfermagem; Pele; Recém-nascido; Estomaterapia; Enfermagem Baseada em Evidências.

\section{RESUMEN}

Objetivo: Identificar estrategias para al prevención de lesiones cutáneas en recién-nacidos (RN) hospitalizados, publicado en revistas científicas de 2013 a 2018. Método: Revisión integral de la literatura realizada en dos momentos de búsqueda en la base de datos, y se seleccionaron 37 estudios publicados entre 2013 y 2018. Resultados: Termorregulación, el uso de antisépticos, uso de emolientes y limpieza del muñón umbilical fueron las recomendaciones más comunes. Las prácticas baseadas en evidencia incluyen aquellas que previenen el riesgo de hipotermia, como el uso de polietileno y contacto piel con piel, que respaldan la atención y garantizan la atención neonatal segura. Conclusión: La prevención de lesiones cutáneas es un tema relevante, sin embargo, existe un falta de evidencia sólida para apoyar de manera segura las prácticas de cuidado del recién nacido. También se observa que la evidencia es insuficientes para abarcar el universo del tema, lo que demuestra que el cuidado de la piel es un tema que requiere inversiones y más investgación.

DESCRIPTORES: Cuidados de enfermería; Piel; Recién nacido; Estomatoterapia; Enfermaría Baseada en la Evidencia.

\section{INTRODUCTION}

Daily, professionals who work in a neonatal unit (NU) face challenges in the exercise of their profession. The nursing staff, specifically, plays a key role in the care of the newborn (NB). One of the concerns of this team is related to skin care, because one of the main functions of this organ is to function as a protective barrier, contributing to thermoregulation, reducing the transepidermal water loss (TEWL), preventing the absorption of chemical agents and protecting against the invasion of microorganisms. However, the NB's skin is thin, fragile, sensitive and presents a deficient epidermal barrier, particularities that, combined with the need for handling, the performance of different procedures, use of drugs and devices to maintain life, expose the neonate to the risk of injuries and infections ${ }^{1,2}$.

The preterm newborn (PTNB), i.e., born before completing 37 weeks of gestational age (GA) and the low-birth-weight newborn, which is born weighing less than 2,500 grams, usually remain in the NU for a long time and are more susceptible to develop lesions ${ }^{1}$. Newborns may present mechanical, chemical, thermal and infectious lesions. The most common injuries are caused by pressure, friction, shear, adhesive removal, incontinence, chemical irritants, drug leakage and burns ${ }^{3}$.

Studies conducted in Brazil show that diaper dermatitis is the most frequent lesion in hospitalized infants $s^{4,5}$. Other injuries that are noteworthy are hematomas, ecchymoses, phlebitis and infiltration caused by puncture and intravenous therapy ${ }^{4,5}$, as well as lesions related to the use of adhesives, umbilical granuloma and nasal injury associated with the use of noninvasive ventilation device ${ }^{4}$.

The skin care practices conducted by the team working in the NU are related to the daily assessment; maintenance of thermal regulation; ways to provide hygiene care; delicate handling; care in the performance of invasive procedures; skin hydration; measures to reduce TEWL; choice of the appropriate product for skin antisepsis; care in the use of devices and removal of adhesives; prevention of pressure, puncture and leakage injuries and dermatitis of the diaper area ${ }^{6,7}$.

Given the above, it is essential to focus attention on the care of the neonate's skin. To protect the NB, the nurse needs to plan the care and, for this, must look for subsidies that support their practice, reducing the risks of iatrogenies and, consequently, contribute to the safety and quality of care. In this regard, there 
is the evidence-based practice (EBP) that aims to incorporate scientific evidence in clinical practice in order to indicate the best care and/or therapy for the patient and, for decision making, considers the experience of the professional, the needs of the patient and the available resources ${ }^{8}$. Although evidence is essential to support care practices, the authors point out that the NB is considered a vulnerable population for conducting studies 9 . Also, pathophysiological specificities of the developing NB may impair the study design and cause bias ${ }^{10}$.

The decision to conduct this study was based on the need to search for evidence on prevention of skin lesions in NB, in order to support the care practice and contribute to improving the quality of care and the safety of neonatal patients.

\section{OBJECTIVE}

To identify strategies for the prevention of skin lesions in hospitalized NBs published in scientific journals from 2013 to 2018.

\section{METHODS}

This is an integrative literature review based on the delimitation of the theme and the guiding question, formulation of objectives, definition of inclusion and exclusion criteria, identification, selection, categorization and evaluation of studies, interpretation of results and presentation of the synthesis of knowledge ${ }^{11}$. To formulate the research question, we used the PICo strategy (P: patient, I: intervention; Co: comparison $)^{12}$. It was then considered: P: newborns; I: prevention of skin lesions; and Co: neonatal unit. Thus, the following research question was delimited: What strategies are available in the literature on the prevention of skin lesions in hospitalized newborns?

Data collection occurred at two times in the literature, first in July 2017 and subsequently in June 2018. Both were performed in the Cochrane Database of Systematic Reviews, MEDLINE (Medical Literature Analysis and Retrieval System Online), LILACS (Literature in the Health Sciences in Latin America and the Caribbean) and BDENF (Nursing Database), using the following descriptors that are inserted in the Health Sciences Descriptors (DeCS): Newborn, Premature Newborn, Skin, Neonatal Intensive Care Units and Neonatal Intensive Care. The Boolean operators "OR" and " $A N D$ " and the descriptors in Portuguese, English and Spanish were used for collection.

As inclusion criteria for the selection of the studies in this integrative review, we used articles published between 2013 and 2018 in national and international journals, written in Portuguese, English, and Spanish, which addressed the prevention of skin lesions in hospitalized NBs. The following material was excluded from the study: editorials, theses, dissertations, books, congress abstracts, non-systematic review studies, articles that did not fit into the time cut, or that did not meet the proposed objective. Articles found in more than one database were considered only once.

The time cut from 2013 to 2018 is justified by the need to search for updated evidence on the theme in question. The inclusion of studies that addressed the NB's skin care from the delivery room to their stay in the NU was chosen. A selection by level of evidence was not performed. The systematic reviews found during the search procedure were not included in the presentation of the results but were used to discuss this study further.

The analysis process began with the evaluation of the title, followed by the reading of the abstracts of the publications in order to verify whether they covered the research question and met the established inclusion criteria. After pre-selection, the studies were read in full in order to avoid selection bias. The selected texts that were not available in full were purchased or requested by the authors by e-mail. The copyright of the authors of the articles was respected. The final sample consisted of 37 articles. Fig. 1 shows how the selection process occurred following PRISMA Flow Diagram ${ }^{13}$.

For the collection of information relevant to the study, a literature review protocol was used ${ }^{11}$ and a database was prepared in the software Excel with the information: author(s), country of origin, year of publication, journal of publication, database, language, sample, study design, central theme, level of evidence and recommendation. To determine the level of evidence, the classification of the Oxford Centre for Evidence-based Medicine was used, where: $1 \mathrm{~A}$ ) systematic review of randomized controlled trials; 1B) randomized controlled clinical 


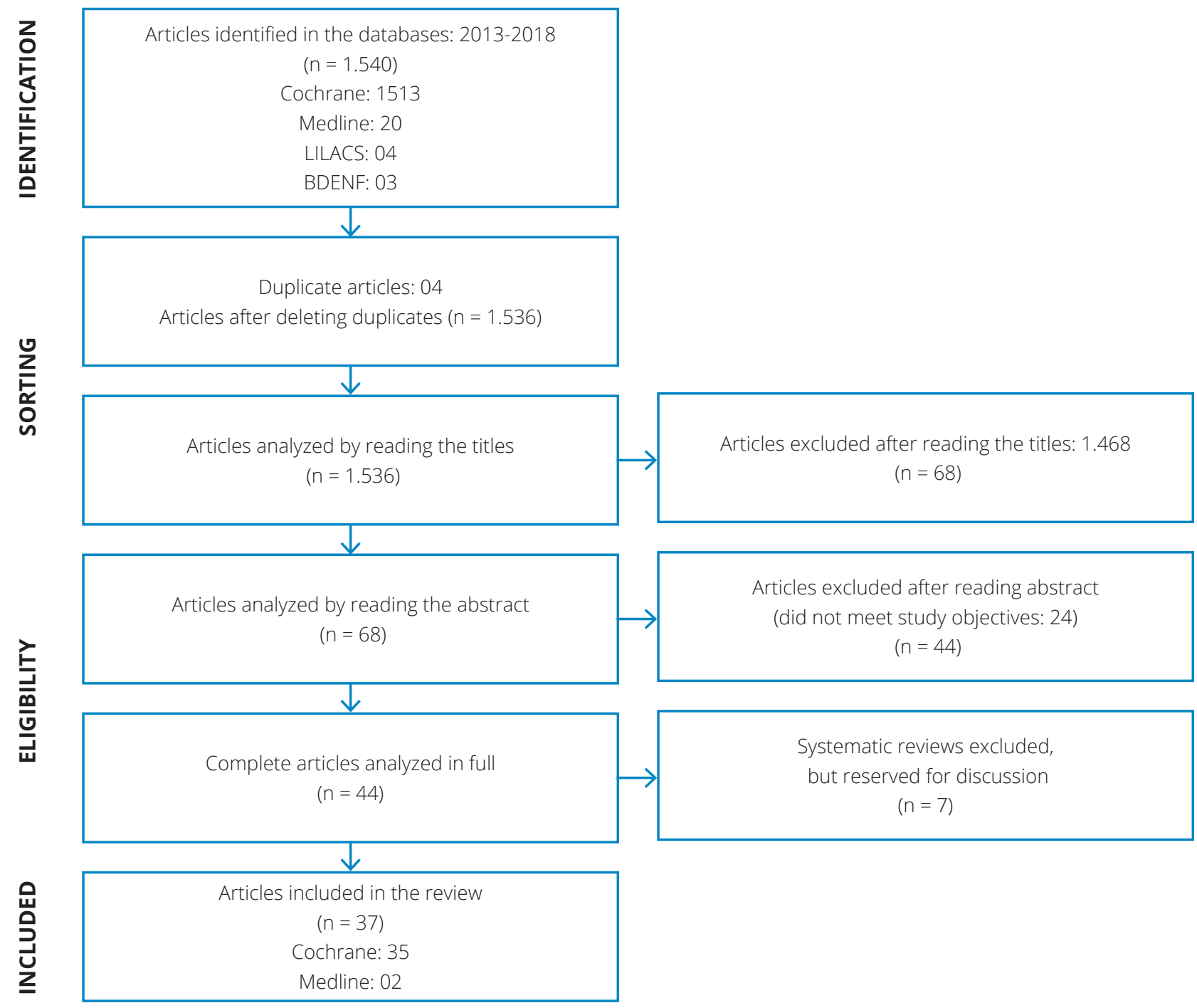

Figure 1. Diagram of the process of inclusion and exclusion of studies, adapted from the PRISMA Flow Diagram model ${ }^{13}$

trial (RCT) with narrow confidence interval; $1 \mathrm{C}$ ) "all or nothing” type therapeutic results; $2 \mathrm{~A}$ ) systematic review of cohort studies; 2B) cohort study and randomized clinical trial (RCT) of lower quality; $2 \mathrm{C}$ ) observation of therapeutic results or ecological studies; $3 \mathrm{~A}$ ) systematic review of case-control studies; 3B) case-control study; 4) case report (including cohort or case-control of lower quality); 5) expert opinion ${ }^{14}$.

In order to ensure methodological accuracy, avoiding bias in the selection and categorization of studies by misinterpretation of the design and results, the research was conducted by two reviewers simultaneously and independently. The sample selection followed the same sequential reading process: title, abstract and full text. The data were grouped according to similar themes and subdivided into categories: thermoregulation, use of emollients, antiseptics, oxygenation devices, venous access, umbilical stump cleaning and general care. The synthesis and critical analysis of the results will be presented descriptively as follows.

\section{RESULTS}

All 37 articles that composed the sample were published in international journals. The RCT was the most commonly found design, with emphasis on the level of evidence $2 \mathrm{~B}$. The following cares were highlighted: measures to promote thermoregulation, use of emollients, use of topical antiseptics, care of the umbilical stump and oxygenation. Their synthesis is presented in Table 1. 
Table 1. Summary of studies included in the review.

\begin{tabular}{|c|c|c|c|c|c|}
\hline $\begin{array}{c}\text { Title } \\
\text { (Reference) }\end{array}$ & $\begin{array}{l}\text { Journal } \\
\text { (Year) }\end{array}$ & $\begin{array}{l}\text { Sample/ } \\
\text { Delin. }\end{array}$ & Intervention & Results & LE \\
\hline $\begin{array}{l}\text { Randomized controlled } \\
\text { trial of vinyl bags versus } \\
\text { thermal mattress to } \\
\text { prevent hypothermia in } \\
\text { extremely } \\
\text { low-gestational-age } \\
\text { infants }\end{array}$ & $\begin{array}{l}\text { Am. J. Perinatol. } \\
\text { (2013) }\end{array}$ & 41 NB; RCT. & $\begin{array}{l}\text { Vinyl bag varsus heating } \\
\text { mattresses to prevent } \\
\text { hypothermia. }\end{array}$ & $\begin{array}{l}\text { Vinyl bags and heating mattress are } \\
\text { equally effective in improving the } \\
\text { intake temperature. Improvements } \\
\text { in other areas, such as delivery } \\
\text { room temperature, may be } \\
\text { necessary to achieve the goal of } \\
\text { preventing hypothermia in this } \\
\text { vulnerable population. }\end{array}$ & $2 B$ \\
\hline $\begin{array}{l}\text { A randomized controlled } \\
\text { trial of plastic drape } \\
\text { for prevention of } \\
\text { hypothermia during } \\
\text { umbilical catheterization }\end{array}$ & $\begin{array}{l}\text { Am. J. Perinatol. } \\
\text { (2013) }\end{array}$ & 60 NB; RCT. & $\begin{array}{l}\text { Polyethylene bag to } \\
\text { prevent hypothermia } \\
\text { during the procedure. }\end{array}$ & $\begin{array}{l}\text { The polyethylene plastic coverage } \\
\text { was superior to the conventional } \\
\text { field in maintaining rectal } \\
\text { temperature and preventing } \\
\text { hypothermia during umbilical } \\
\text { catheterization. }\end{array}$ & $2 B$ \\
\hline $\begin{array}{l}\text { A randomized trial of } \\
\text { exothermic mattresses } \\
\text { for preterm newborns in } \\
\text { polyethylene bags }\end{array}$ & $\begin{array}{l}\text { Pediatrics } \\
\text { (2013) }\end{array}$ & 72 NB; RCT. & $\begin{array}{l}\text { Polyethylene bag } \\
\text { associated to the } \\
\text { exothermic matrix at the } \\
\text { temperature of the PTNB. }\end{array}$ & $\begin{array}{l}\text { The use of exothermic matrix } \\
\text { associated with the polyethylene } \\
\text { bag in PTNBs resulted in more } \\
\text { children with temperatures outside } \\
\text { the normal range and more } \\
\text { hyperthermia on admission to the } \\
\text { NU. }\end{array}$ & $2 B$ \\
\hline $\begin{array}{l}\text { Plastic bags for prevention } \\
\text { of hypothermia in } \\
\text { preterm and low birth } \\
\text { weight infants }{ }^{18}\end{array}$ & $\begin{array}{l}\text { Pediatrics } \\
\text { (2013) }\end{array}$ & 104 NB; RCT. & $\begin{array}{l}\text { Plastic bag at birth } \\
\text { maintains the } \\
\text { normothermia of PTNBs } \\
\text { and low weight NBs. }\end{array}$ & $\begin{array}{l}\text { The use of a plastic bag at } \\
\text { birth compared to standard } \\
\text { thermoregulatory care has reduced } \\
\text { hypothermia without resulting in } \\
\text { hyperthermia and is low technology, } \\
\text { low-cost tool for locations where } \\
\text { resources are limited. }\end{array}$ & $2 B$ \\
\hline $\begin{array}{l}\text { Randomized trial } \\
\text { of plastic bags to } \\
\text { prevent term neonatal } \\
\text { hypothermia in a } \\
\text { resource-poor setting } 19\end{array}$ & $\begin{array}{l}\text { Pediatrics } \\
\text { (2013) }\end{array}$ & $271 \mathrm{NB} ; \mathrm{RCT}$. & $\begin{array}{l}\text { Plastic bags in Term NB } \\
\text { reduce hypothermia by } 1 \\
\text { hour after birth. }\end{array}$ & $\begin{array}{l}\text { Use of plastic bags at birth reduced } \\
\text { the incidence of hypothermia by } 1 \\
\text { hour after birth in term NBs, born } \\
\text { in a poor resource setting, but most } \\
\text { neonates remained hypothermic. }\end{array}$ & $2 B$ \\
\hline $\begin{array}{l}\text { Effect of early skin-to-skin } \\
\text { contact following normal } \\
\text { delivery on incidence of } \\
\text { hypothermia in neonates } \\
\text { more than } 1800 \mathrm{~g} \text { : } \\
\text { randomized control trial }{ }^{20}\end{array}$ & $\begin{array}{l}\text { J. Perinatol. } \\
\text { (2014) }\end{array}$ & 100 NB; RCT. & $\begin{array}{l}\text { Early skin-to-skin contact } \\
\text { in the incidence of } \\
\text { hypothermia in low weight } \\
\text { NBs. }\end{array}$ & $\begin{array}{l}\text { NBs in skin-to-skin contact achieved } \\
\text { rapid thermal control compared } \\
\text { to the control group. Early skin- } \\
\text { to-skin contact for } 24 \mathrm{~h} \text { after } \\
\text { birth decreases the incidence of } \\
\text { hypothermia in the first } 48 \text { h of } \\
\text { life and needs to be aggressively } \\
\text { promoted in terms NBs and } \\
\text { PTNBs to reduce the incidence of } \\
\text { hypothermia. }\end{array}$ & $2 B$ \\
\hline $\begin{array}{l}\text { Heat loss prevention } \\
\text { (help) after birth in } \\
\text { preterm infants using } \\
\text { vinyl isolation bag or } \\
\text { polyethylene wrap }\end{array}$ & $\begin{array}{l}\text { JOGN Nurs. } \\
\text { (2014) }\end{array}$ & 59 NB; RCT. & $\begin{array}{l}\text { Vinyl or polyethylene bag } \\
\text { to prevent hypothermia in } \\
\text { PTNBs. }\end{array}$ & $\begin{array}{l}\text { To involve PTNBs with gestational } \\
\text { age } \leq 32 \text { weeks in vinyl bags } \\
\text { immediately after birth is } \\
\text { associated with a lower incidence of } \\
\text { hypothermia. }\end{array}$ & $2 B$ \\
\hline $\begin{array}{l}\text { Total body polyethylene } \\
\text { wraps for preventing } \\
\text { hypothermia in preterm } \\
\text { infants: a randomized tria }{ }^{22}\end{array}$ & $\begin{array}{l}\text { J. Pediatr. } \\
\text { (2014) }\end{array}$ & 100 NB; RCT. & $\begin{array}{l}\text { Polyethylene bag } \\
\text { (body and head) or } \\
\text { (up to shoulders) } \\
\text { thermoregulation of } \\
\text { PTNBs. }\end{array}$ & $\begin{array}{l}\text { Total body involvement is } \\
\text { comparable to the body to shoulder } \\
\text { coverage in the prevention of } \\
\text { postnatal heat loss in PTNBs. }\end{array}$ & 1B \\
\hline
\end{tabular}


Table 1. Continuation...

\begin{tabular}{|c|c|c|c|c|c|}
\hline $\begin{array}{c}\text { Title } \\
\text { (Reference) }\end{array}$ & $\begin{array}{l}\text { Journal } \\
\text { (Year) }\end{array}$ & $\begin{array}{l}\text { Sample/ } \\
\text { Delin. }\end{array}$ & Intervention & Results & LE \\
\hline $\begin{array}{l}\text { Thermal Blanket to Improve } \\
\text { Thermoregulation in Preterm } \\
\text { Infants: a Randomized } \\
\text { Controlled TriaP }\end{array}$ & $\begin{array}{l}\text { Pediatr. Crit. } \\
\text { Care Med. } \\
\text { (2015) }\end{array}$ & 80 NB; RCT. & $\begin{array}{l}\text { Thermal blanket and radi- } \\
\text { ant cradle at thermoregu- } \\
\text { lation and blood pressure } \\
\text { of low weight NBs. }\end{array}$ & $\begin{array}{l}\text { The use of thermal blanket im- } \\
\text { proved hypothermia, which was } \\
\text { related to fewer cases of hypoten- } \\
\text { sion and less use of dopamine. }\end{array}$ & $2 B$ \\
\hline $\begin{array}{l}\text { Randomized trial of } \\
\text { occlusive wrap for heat } \\
\text { loss prevention in preterm } \\
\text { infants }{ }^{24}\end{array}$ & $\begin{array}{l}\text { J. Pediatr. } \\
\text { (2015) }\end{array}$ & 801 NB; RCT. & $\begin{array}{l}\text { Occlusive wrapping at birth } \\
\text { reduces PTNB mortality. }\end{array}$ & $\begin{array}{l}\text { The application of occlusive wrap- } \\
\text { ping in PTNB immediately after } \\
\text { birth results in higher mean body } \\
\text { temperature but does not reduce } \\
\text { mortality. }\end{array}$ & $1 \mathrm{~B}$ \\
\hline $\begin{array}{l}\text { Weight at weaning of } \\
\text { preterm infants from } \\
\text { incubator to bassinet: a } \\
\text { randomized clinical trial25 }\end{array}$ & $\begin{array}{l}\text { Am. J. Perinatol. } \\
\text { (2014) }\end{array}$ & $21 \mathrm{NB} ; \mathrm{RCT}$. & $\begin{array}{l}\text { Thermal response of NBs } \\
\text { removed from the incuba- } \\
\text { tor with } 1,500 \text { or } 1,600 \mathrm{~g} \text {. }\end{array}$ & $\begin{array}{l}\text { Weaning of deficient weight NBs } \\
(1,500 \mathrm{~g}) \text { from an incubator to a } \\
\text { heating cradle is feasible and has } \\
\text { no significant deleterious effects on } \\
\text { weight gain. }\end{array}$ & $2 \mathrm{~B}$ \\
\hline $\begin{array}{l}\text { Keeping babies warm: } \\
\text { a non-inferiority trial of } \\
\text { a conductive thermal } \\
\text { mattress }^{26}\end{array}$ & $\begin{array}{l}\text { Arch. Dis. Child. } \\
\text { Fetal Neonatal } \\
\text { Ed. (2015) }\end{array}$ & 160 NB; RCT. & $\begin{array}{l}\text { Conductive thermal mat- } \\
\text { tress or standard care for } \\
\text { heating: low weight NB. }\end{array}$ & $\begin{array}{l}\text { The short-term use of conductive } \\
\text { thermal mattresses compared to } \\
\text { radiant heaters and other heating } \\
\text { modes is not inferior to standard } \\
\text { care and is useful in maintaining } \\
\text { body temperature without adverse } \\
\text { effects. }\end{array}$ & $2 \mathrm{~B}$ \\
\hline $\begin{array}{l}\text { Polyethylene versus cotton } \\
\text { cap as an adjunct to body } \\
\text { wrap in preterm infants }{ }^{27}\end{array}$ & $\begin{array}{l}\text { Pediatr. Int. } \\
\text { (2017) }\end{array}$ & 80 NB; RCT. & $\begin{array}{l}\text { Polyethylene or cotton cap } \\
\text { associated with polyeth- } \\
\text { ylene bag: thermoregula- } \\
\text { tion. }\end{array}$ & $\begin{array}{l}\text { whe combined use of polyethylene } \\
\text { ylene cap was associated with a } \\
\text { significantly higher mean post-sta- } \\
\text { bilization temperature compared to } \\
\text { polyethylene wrap on the body and } \\
\text { cotton cap. }\end{array}$ & $2 \mathrm{~B}$ \\
\hline $\begin{array}{l}\text { Using polyethylene plastic } \\
\text { bag to prevent moderate } \\
\text { hypothermia during } \\
\text { transport in very low } \\
\text { birth weight infants: a } \\
\text { randomized trial28 }\end{array}$ & $\begin{array}{l}\text { J. Perinatol. } \\
\text { (2018) }\end{array}$ & 108 NB; RCT. & $\begin{array}{l}\text { Very low weight NBs in } \\
\text { plastic bags during trans- } \\
\text { port reduces hypothermia. }\end{array}$ & $\begin{array}{l}\text { Placing very low-weight NBs in } \\
\text { polyethylene plastic bags during } \\
\text { transport reduces the occurrence of } \\
\text { moderate hypothermia. }\end{array}$ & $2 \mathrm{~B}$ \\
\hline $\begin{array}{l}\text { Wrapping newborn } \\
\text { infants in cloth and } \\
\text { newspaper after delivery } \\
\text { led to higher temperatures } \\
\text { on arrival at the neonatal } \\
\text { intensive care unit } 29\end{array}$ & $\begin{array}{c}\text { Acta Paediatr. } \\
\text { (2018) }\end{array}$ & 100 NB; RCT. & $\begin{array}{l}\text { Thermal properties of } \\
\text { newspaper sheets be- } \\
\text { tween cotton sheets for } \\
\text { NBs. }\end{array}$ & $\begin{array}{l}\text { Wrapping NBs in two sheets of fab- } \\
\text { ric with a layer of newspaper sheet } \\
\text { resulted in higher body temperature } \\
\text { on arrival at the NICU and after one } \\
\text { hour. }\end{array}$ & $2 B$ \\
\hline $\begin{array}{l}\text { Mechanism for } \\
\text { prevention of infection } \\
\text { in preterm neonates } \\
\text { by topical emollients: a } \\
\text { randomized, controlled } \\
\text { clinical triaßo }\end{array}$ & $\begin{array}{l}\text { Pediatr. Infect. } \\
\text { Dis. J. (2014) }\end{array}$ & $491 \mathrm{NB} ; \mathrm{RCT}$. & $\begin{array}{l}\text { Emollient in the skin con- } \\
\text { dition score and risk of } \\
\text { systemic infection. }\end{array}$ & $\begin{array}{l}\text { Emollient therapy is associated with } \\
\text { improved weight gain, reduced risk } \\
\text { of infection and associated neo- } \\
\text { natal mortality of PTNBs, and is a } \\
\text { potentially promising intervention } \\
\text { for use in low-resource settings. }\end{array}$ & $2 B$ \\
\hline $\begin{array}{l}\text { Application of moisturizer } \\
\text { to neonates prevents } \\
\text { development of atopic } \\
\text { dermatitis }^{31}\end{array}$ & $\begin{array}{l}\text { J. allergy clin. } \\
\text { Immunol. } \\
\text { (2014) }\end{array}$ & 118 NB; RCT. & $\begin{array}{l}\text { Moisturizer prevents } \\
\text { atopic dermatitis and al- } \\
\text { lergic sensitization. }\end{array}$ & $\begin{array}{l}\text { Daily application of moisturizer dur- } \\
\text { ing the first } 32 \text { weeks of life reduces } \\
\text { the risk of atopic dermatitis/eczema } \\
\text { in infants. Allergic sensitization } \\
\text { during this period is associated with } \\
\text { the presence of eczematous skin, } \\
\text { not with the use of a moisturizer. }\end{array}$ & $2 B$ \\
\hline
\end{tabular}


Table 1. Continuation...

\begin{tabular}{|c|c|c|c|c|c|}
\hline $\begin{array}{c}\text { Title } \\
\text { (Reference) }\end{array}$ & $\begin{array}{l}\text { Journal } \\
\text { (Year) }\end{array}$ & $\begin{array}{l}\text { Sample/ } \\
\text { Delin. }\end{array}$ & Intervention & Results & LE \\
\hline $\begin{array}{l}\text { The effect of topical } \\
\text { ointment on neonatal } \\
\text { sepsis in preterm } \\
\text { infants }^{32}\end{array}$ & $\begin{array}{l}\text { J. Matern. Fetal } \\
\text { Neonatal Med. } \\
\text { (2014) }\end{array}$ & 197 NB; RCT. & $\begin{array}{l}\text { Effects of topical ointment } \\
\text { on neonatal sepsis. }\end{array}$ & $\begin{array}{l}\text { Topical application of emollient } \\
\text { during the first two postnatal weeks } \\
\text { did not affect the risk of neonatal } \\
\text { sepsis in PTNBs, although it altered } \\
\text { the bacterial flora on the skin by } \\
\text { comparison with the routine care } \\
\text { group. }\end{array}$ & $2 B$ \\
\hline $\begin{array}{l}\text { Influence of sunflower } \\
\text { seed oil on the skin barrier } \\
\text { function of preterm } \\
\text { infants: a randomized } \\
\text { controlled triaß33}\end{array}$ & $\begin{array}{l}\text { Dermatology } \\
\text { (2014) }\end{array}$ & 22 NB; RCT. & $\begin{array}{l}\text { Sunflower seed oil in the } \\
\text { development of a skin } \\
\text { barrier in PTNB. }\end{array}$ & $\begin{array}{l}\text { The application of sunflower seed } \\
\text { oil may delay the maturation of the } \\
\text { postnatal skin barrier in PTNB. }\end{array}$ & $2 B$ \\
\hline $\begin{array}{l}\text { Effect of emollient therapy } \\
\text { on clinical outcomes } \\
\text { in preterm neonates in } \\
\text { Pakistan: a randomised } \\
\text { controlled triaß34 }\end{array}$ & $\begin{array}{l}\text { Arch. Dis. Child. } \\
\text { Fetal Neonatal } \\
\text { Ed. (2015) }\end{array}$ & 258 NB; RCT. & $\begin{array}{l}\text { Effectiveness of topical } \\
\text { applications of coconut oil } \\
\text { in PTNB. }\end{array}$ & $\begin{array}{l}\text { Topical emollient therapy was effec- } \\
\text { tive in maintaining skin integrity and } \\
\text { reducing the risk of bloodstream } \\
\text { infection in PTNBs at a tertiary } \\
\text { hospital in Pakistan. }\end{array}$ & $2 \mathrm{~B}$ \\
\hline $\begin{array}{l}\text { Topical Oil Application and } \\
\text { Trans-Epidermal Water } \\
\text { Loss in Preterm Very Low } \\
\text { Birth Weight Infants-A } \\
\text { Randomized Triaß35 }\end{array}$ & $\begin{array}{l}\text { J. Trop. Pediatr } \\
\text { (2015) }\end{array}$ & 74 NB; RCT. & $\begin{array}{l}\text { Topical application of } \\
\text { coconut oil in transepider- } \\
\text { mal water loss in PTNB. }\end{array}$ & $\begin{array}{l}\text { The application of coconut oil re- } \\
\text { duced TEWL without increasing skin } \\
\text { colonization in very low weight NBs. }\end{array}$ & $2 \mathrm{~B}$ \\
\hline $\begin{array}{l}\text { Topical Coconut Oil in } \\
\text { Very Preterm Infants: an } \\
\text { Open-Label Randomised } \\
\text { Controlled Trial }\end{array}$ & $\begin{array}{l}\text { Neonatol. } \\
\text { (2017) }\end{array}$ & 72 NB; RCT. & $\begin{array}{l}\text { Viability, safety and the ef- } \\
\text { fects of topical coconut oil } \\
\text { on the skin condition. }\end{array}$ & $\begin{array}{l}\text { Topical coconut oil maintained bet- } \\
\text { ter skin condition in very premature } \\
\text { NBs, without adverse effects. }\end{array}$ & $2 B$ \\
\hline $\begin{array}{l}\text { A randomized controlled } \\
\text { trial of } 1 \% \text { aqueous } \\
\text { chlorhexidine gluconate } \\
\text { compared with } 10 \% \\
\text { povidone-iodine for topical } \\
\text { antiseptic in neonates: } \\
\text { effects on blood culture } \\
\text { contamination rates }{ }^{37}\end{array}$ & $\begin{array}{l}\text { Infect. } \\
\text { Control Hosp. } \\
\text { Epidemiol. } \\
\text { (2013) }\end{array}$ & 344 NB; RCT & $\begin{array}{l}\text { To compare topical anti- } \\
\text { septic: chlorhexidine 1\% } \\
\text { and povidone-iodine } 10 \% \text {. }\end{array}$ & $\begin{array}{l}\text { One percent of } \mathrm{CHG} \text { was more } \\
\text { effective than } 10 \% \text { of PI in reducing } \\
\text { blood culture contamination rates, } \\
\text { and no contact dermatitis was } \\
\text { observed. }\end{array}$ & $2 \mathrm{~B}$ \\
\hline $\begin{array}{l}\text { 2\% chlorhexidine- } 70 \% \\
\text { isopropyl alcohol versus } \\
\text { 10\% povidone-iodine for } \\
\text { insertion site cleaning } \\
\text { before central line insertion } \\
\text { in preterm infants: a } \\
\text { randomised tria }{ }^{\beta 8}\end{array}$ & $\begin{array}{l}\text { Arch. Dis. Child. } \\
\text { Fetal Neonatal } \\
\text { Ed. (2018) }\end{array}$ & 304 NB; RCT. & $\begin{array}{l}\text { Chlorhexidine } 2 \% \text { in al- } \\
\text { cohol or povidone-iodine } \\
10 \% \text { in water, in the pre- } \\
\text { vention of infection of the } \\
\text { bloodstream in the skin } \\
\text { asepsis before catheter } \\
\text { insertion. }\end{array}$ & $\begin{array}{l}\text { No difference was found in the } \\
\text { bloodstream infection rate between } \\
\text { PTNBs treated with } 2 \% \text { chlorhexi- } \\
\text { dine in alcohol and } 10 \% \text { povidone- } \\
\text { iodine in water and more infants } \\
\text { treated with povidone-iodine } \\
\text { showed thyroid dysfunction. }\end{array}$ & $2 \mathrm{~B}$ \\
\hline $\begin{array}{l}0.2 \% \text { chlorhexidine } \\
\text { acetate as skin } \\
\text { disinfectant prevents } \\
\text { skin lesions in extremely } \\
\text { preterm infants: a } \\
\text { preliminary report }^{39}\end{array}$ & $\begin{array}{l}\text { Arch. Dis. Child. } \\
\text { Fetal Neonatal } \\
\text { Ed. (2018) }\end{array}$ & $\begin{array}{l}304 \text { NB; Ret- } \\
\text { rospective } \\
\text { cohort. }\end{array}$ & $\begin{array}{l}\text { Skin lesions and blood- } \\
\text { stream infection associ- } \\
\text { ated with the central } \\
\text { catheter in extreme } \\
\text { PTNBs with chlorhexidine } \\
\text { gluconate } 0.5 \% \text { in alcohol } \\
70 \% \text { or chlorhexidine } \\
\text { acetate } 0.2 \% \text {. }\end{array}$ & $\begin{array}{l}\text { The use of } 0.2 \% \text { chlorhexidine } \\
\text { acetate as a skin disinfectant in } \\
\text { extreme PTNBs resulted in a sta- } \\
\text { tistically significant reduction of } \\
\text { skin lesions, without increasing the } \\
\text { risk of infection compared to } 0.5 \% \\
\text { chlorhexidine gluconate in alcohol } \\
70 \% \text {. }\end{array}$ & $2 \mathrm{~B}$ \\
\hline
\end{tabular}


Table 1. Continuation...

\begin{tabular}{|c|c|c|c|c|c|}
\hline $\begin{array}{c}\text { Title } \\
\text { (Reference) }\end{array}$ & $\begin{array}{l}\text { Journal } \\
\text { (Year) }\end{array}$ & $\begin{array}{l}\text { Sample/ } \\
\text { Delin. }\end{array}$ & Intervention & Results & LE \\
\hline $\begin{array}{l}\text { Evaluation of efficacy } \\
\text { of skin cleansing with } \\
\text { chlorhexidine in prevention } \\
\text { of neonatal nosocomial } \\
\text { sepsis - a randomized } \\
\text { controlled trial}{ }^{40}\end{array}$ & $\begin{array}{l}\text { J. Matern. Fetal } \\
\text { Neonatal Med. } \\
\text { (2016) }\end{array}$ & 140 NB; RCT. & $\begin{array}{l}\text { Effectiveness of chlorhexi- } \\
\text { dine skin cleansing in the } \\
\text { prevention of nosocomial } \\
\text { sepsis. }\end{array}$ & $\begin{array}{l}\text { Chlorhexidine skin cleansing de- } \\
\text { creases the incidence of sepsis by } \\
\text { blood culture and can be an easy } \\
\text { and inexpensive intervention to } \\
\text { reduce neonatal sepsis in countries } \\
\text { where the neonatal mortality rate is } \\
\text { high because of sepsis. }\end{array}$ & $2 B$ \\
\hline $\begin{array}{l}\text { Effect of topical application } \\
\text { of chlorhexidine for } \\
\text { umbilical cord care } \\
\text { in comparison with } \\
\text { conventional dry cord care } \\
\text { on the risk of neonatal } \\
\text { sepsis: a randomized } \\
\text { controlled trial }{ }^{41}\end{array}$ & $\begin{array}{l}\text { J. Trop. Pediatr. } \\
\text { (2013) }\end{array}$ & 140 NB; RCT. & $\begin{array}{l}\text { Chlorhexidine in the um- } \\
\text { bilical cord versus dry care } \\
\text { to prevent sepsis. }\end{array}$ & $\begin{array}{l}\text { The use of chlorhexidine in the care } \\
\text { of the umbilical cord prevents sep- } \\
\text { sis at the NU. }\end{array}$ & 1B \\
\hline $\begin{array}{l}\text { Impact of chlorhexidine } \\
\text { cleansing of the umbilical } \\
\text { cord on cord separation } \\
\text { time and neonatal } \\
\text { mortality in comparison to } \\
\text { dry cord care - a nursery- } \\
\text { based randomized } \\
\text { controlled tria }{ }^{42}\end{array}$ & $\begin{array}{l}\text { J. Matern. Fetal } \\
\text { Neonatal Med. } \\
\text { (2014) }\end{array}$ & 140 NB; RCT. & $\begin{array}{l}\text { Impact of cleaning the } \\
\text { umbilical stump with } \\
\text { chlorhexidine versus } \\
\text { maintenance of the dry } \\
\text { umbilical stump. }\end{array}$ & $\begin{array}{l}\text { The use of chlorhexidine in umbili- } \\
\text { cal stump care shortens the sepa- } \\
\text { ration time and reduces neonatal } \\
\text { mortality in the NU. This interven- } \\
\text { tion can be used to reduce neona- } \\
\text { tal mortality. }\end{array}$ & $2 B$ \\
\hline $\begin{array}{l}\text { Two methods of cord care } \\
\text { in high-risk newborns: } \\
\text { their effects on hydration, } \\
\text { temperature, pH, and } \\
\text { floras of the cord area }\end{array}$ & $\begin{array}{l}\text { J. Child Health } \\
\text { Care. } \\
\text { (2015) }\end{array}$ & 72 NB; RCT. & $\begin{array}{l}\text { Water versus alcohol in } \\
\text { hydration, temperature, } \\
\mathrm{pH} \text { and bacterial flora of } \\
\text { the umbilical stump. }\end{array}$ & $\begin{array}{l}\text { The clean and dry care method, } \\
\text { which uses water, may be sufficient } \\
\text { or even better than alcohol to } \\
\text { maintain the physiological environ- } \\
\text { ment of the stump surface, with } \\
\text { less chance of infection in the NU. }\end{array}$ & $2 \mathrm{~B}$ \\
\hline $\begin{array}{l}\text { A comparison of nasal } \\
\text { trauma in preterm infants } \\
\text { extubated to either heated } \\
\text { humidified high-flow } \\
\text { nasal cannulae or nasal } \\
\text { continuous positive airway } \\
\text { pressure } 44\end{array}$ & $\begin{array}{l}\text { Eur. J. Pediatr. } \\
\text { (2014) }\end{array}$ & 132 NB; RCT. & $\begin{array}{l}\text { To verify the incidence of } \\
\text { nasal trauma in PTNBs } \\
\text { in CPAP or high-flow sys- } \\
\text { tems, and to evaluate the } \\
\text { effect of two nasal protec- } \\
\text { tors. }\end{array}$ & $\begin{array}{l}\text { The high-flow system resulted in } \\
\text { less nasal trauma than CPAP and } \\
\text { was more significant in NBs }<28 \\
\text { weeks of GA. The use of protective } \\
\text { dressings did not decrease nasal } \\
\text { trauma in NBs in CPAP. }\end{array}$ & $2 \mathrm{~B}$ \\
\hline $\begin{array}{l}\text { A comparative } \\
\text { effectiveness study of } \\
\text { continuous positive airway } \\
\text { pressure-related skin } \\
\text { breakdown when using } \\
\text { different nasal interfaces } \\
\text { in the extremely low birth } \\
\text { weight neonate }\end{array}$ & $\begin{array}{c}\text { Appl. Nurs. Res. } \\
\text { (2015) }\end{array}$ & 78 NB; RCT. & $\begin{array}{l}\text { Differences in frequency, } \\
\text { the severity of nasal le- } \\
\text { sions and risk factors } \\
\text { associated with the use of } \\
\text { different interfaces during } \\
\text { CPAP in NBs < 1,500 g: } \\
\text { Nasal prong; nasal mask; } \\
\text { or other nasal mask/ } \\
\text { prong. }\end{array}$ & $\begin{array}{l}\text { Fewer lesions were detected in the } \\
\text { alternate interface group. Predic- } \\
\text { tors of injury included a number } \\
\text { of days in CPAP and current mean } \\
\text { postnatal age. Best practices should } \\
\text { include proper device size selection } \\
\text { and positioning of the CPAP device } \\
\text { with a focused skin assessment, } \\
\text { including rapid intervention for skin } \\
\text { lesion. }\end{array}$ & $2 \mathrm{~B}$ \\
\hline $\begin{array}{l}\text { Peripherally inserted } \\
\text { central venous catheters: } \\
\text { frequency of complications in } \\
\text { premature newborn depends } \\
\text { on the insertion site }\end{array}$ & $\begin{array}{l}\text { J. Perinatol. } \\
\text { (2014) }\end{array}$ & 62 NB; RCT. & $\begin{array}{l}\text { Axillary vein at percuta- } \\
\text { neous central catheter } \\
\text { insertion: reduction of } \\
\text { complications. }\end{array}$ & $\begin{array}{l}\text { The use of the axillary vein as a site } \\
\text { of insertion of a PICC line correlated } \\
\text { with significantly lower complica- } \\
\text { tions than in other sites of insertion } \\
\text { in PTNBs. }\end{array}$ & $2 B$ \\
\hline
\end{tabular}


Table 1. Continuation...

\begin{tabular}{|c|c|c|c|c|c|}
\hline $\begin{array}{c}\text { Title } \\
\text { (Reference) }\end{array}$ & $\begin{array}{l}\text { Journal } \\
\text { (Year) }\end{array}$ & $\begin{array}{l}\text { Sample/ } \\
\text { Delin. }\end{array}$ & Intervention & Results & LE \\
\hline $\begin{array}{l}\text { Phototherapy rash } \\
\text { in newborn infants: } \\
\text { does it differ between } \\
\text { conventional and } \\
\text { light emitting diode } \\
\text { phototherapy? }\end{array}$ & $\begin{array}{l}\text { Pediatr. } \\
\text { Dermatol. } \\
\text { (2013) }\end{array}$ & 58 NB; RCT. & $\begin{array}{l}\text { Incidence and extent of } \\
\text { skin eruptions in different } \\
\text { phototherapy devices. }\end{array}$ & $\begin{array}{l}\text { Bilirubin control levels were similar } \\
\text { for both groups. The frequency of } \\
\text { skin eruptions was 36\% in the con- } \\
\text { ventional phototherapy (CF) group } \\
\text { and 33\% in the LED phototherapy } \\
\text { (LF) group. The skin eruptions were } \\
\text { macules in } 22.4 \% \text {, papules in } 8.6 \% \\
\text { and maculopapular eruptions in } \\
\text { 3.4\% of infants. There were no } \\
\text { differences in the incidence and } \\
\text { extent of skin eruptions in PTNBs } \\
\text { who received CF or FL. }\end{array}$ & $2 \mathrm{~B}$ \\
\hline $\begin{array}{l}\text { Effect of trunk-to-head } \\
\text { bathing on physiological } \\
\text { responses in newborns }\end{array}$ & $\begin{array}{l}\text { JOGN Nurs. } \\
\text { (2014) }\end{array}$ & 62 NB; RCT. & $\begin{array}{l}\text { Effect of the bath (trunk } \\
\text { to head) and (head to the } \\
\text { trunk) on the stability of } \\
\text { the NB. }\end{array}$ & $\begin{array}{l}\text { NBs who were bathed from trunk } \\
\text { to head and whose heads became } \\
\text { wet for shorter periods benefited } \\
\text { from the faster recovery of body } \\
\text { temperature and reduction of heat } \\
\text { loss due to evaporation. }\end{array}$ & $2 \mathrm{~B}$ \\
\hline $\begin{array}{l}\text { Comparing the effects of } \\
\text { swaddle and conventional } \\
\text { bathing methods on } \\
\text { behavioral responses in } \\
\text { preterm neonates }{ }^{49}\end{array}$ & $\begin{array}{l}\text { Iran. J. } \\
\text { Neonatal. } \\
\text { (2016) }\end{array}$ & $50 \mathrm{NB} ; \mathrm{RCT}$. & $\begin{array}{l}\text { Swaddle and conventional } \\
\text { methods of bathing in } \\
\text { behavioral responses. }\end{array}$ & $\begin{array}{l}\text { Swaddle can reduce neonatal stress } \\
\text { during bathing and can be used as } \\
\text { a suitable and pleasant method for } \\
\text { PTNBs in NU. }\end{array}$ & $2 \mathrm{~B}$ \\
\hline $\begin{array}{l}\text { Diaper dermatitis care of } \\
\text { newborns human breast } \\
\text { milk or barrier cream }\end{array}$ & $\begin{array}{l}\text { J. Clin. Nurs. } \\
\text { (2014) }\end{array}$ & 63 NB; RCT. & $\begin{array}{l}\text { Breast milk or barrier } \\
\text { cream to heal diaper der- } \\
\text { matitis in NU. }\end{array}$ & $\begin{array}{l}\text { The barrier cream offers more } \\
\text { effective results than the treatment } \\
\text { with human breast milk, particularly } \\
\text { in the treatment of infants with } \\
\text { moderate to severe dermatitis. }\end{array}$ & $2 \mathrm{~B}$ \\
\hline $\begin{array}{l}\text { Skin care product } \\
\text { evaluation in a group of } \\
\text { critically ill, premature } \\
\text { neonates: a descriptive } \\
\text { study }\end{array}$ & $\begin{array}{l}\text { J. Wound } \\
\text { Ostomy } \\
\text { Continence } \\
\text { Nurs. (2014) }\end{array}$ & $\begin{array}{c}29 \text { NB; } \\
\text { Descriptive. }\end{array}$ & $\begin{array}{l}\text { Skin care products } \\
\text { in general condition, } \\
\text { perineal erythema and } \\
\text { pain. }\end{array}$ & $\begin{array}{l}\text { The use of a skin care product line } \\
\text { was not associated with significant } \\
\text { increases in overall NB skin } \\
\text { condition measured with Neonatal } \\
\text { Skin Condition Score, perineal } \\
\text { erythema measured with Skin } \\
\text { Erythema Scale or pain. }\end{array}$ & 4 \\
\hline
\end{tabular}

\section{DISCUSSION}

The care to prevent skin lesions in NBs found in this review were divided into seven categories: thermoregulation, use of emollients, antiseptics, oxygenation devices, venous access, cleaning of the umbilical stump and general care.

\section{Thermoregulation}

In this category, 15 studies addressing NB thermoregulation were included. Thermal stability is an essential factor for $\mathrm{NBs}$ and requires constant attention from the professional team that works to assist the newborn. According to the World Health Organization (WHO), the normal body temperature range of $\mathrm{NBs}$ is between 36.5 and $37.5^{\circ} \mathrm{C}^{52}$. The increased risk of hypothermia occurs in the first minutes after birth when the newborn adapts to the extrauterine environment. If thermal protection measures are not put in place immediately, the core temperature may drop at a rate of 0.1 to $0.3{ }^{\circ} \mathrm{C}$ per minute, compromising the clinical stability of the baby ${ }^{19,53}$. Neonatal hypothermia 
can cause stress from cold and demand higher energy expenditure of the NB, consequently increasing the risk of morbidity and mortality ${ }^{54}$. Care to prevent hypothermia at birth is essential in the care of the newborn, while still in the delivery room. By analyzing the data of this review, it was noticed that this aspect generates concerns in researchers, considering the number of studies found.

Skin-to-skin contact was shown to decrease the incidence of hypothermia in term NBs or late PTNBs and in babies with a weight greater than or equal to 1,800 grams, when started in the first hours after birth and maintained, with minimal interruption, during the first 24 hours of life ${ }^{20}$. There is evidence that skin-toskin contact, for at least six hours a day, contributes to better weight gain and reduced length of hospital stay, in addition to being a low-cost and easy-to-perform practice $^{55}$. To the thermoregulatory effect, the benefits of this practice are added for better neurobehavioral and psychoactive development, for improved bonding between mother and baby, adequate sensory stimulation, decreased pain and stress of PTNBs, among others ${ }^{56}$.

Several studies indicate the use of polyethylene or vinyl bags to involve PTNBs immediately after $\operatorname{birth}^{18,19,22,28}$. At some times, these practices were also associated with other measures in order to identify the best way to achieve and maintain thermoregulation in patients. In PTNBs wrapped in a polyethylene bag from the neck down, the additional use of a polyethylene cap dressed in the still moist head, immediately after birth, was associated with significant improvement in the mean temperature ${ }^{27}$.

PTNBs have a poorly developed muscle mass and scarce subcutaneous tissue, which reduces thermal insulation. Eccrine glands, epithelial cells responsible for sweating, are not functional due to the relatively large body area concerning the weight of these babies and the physiological immaturity. In addition to these aspects, NBs can present heat loss through evaporation, radiation, convection and conduction. Evaporative calorie loss, which corresponds to TEWL, is approximately 10 times higher in PTNBs than in term newborns ${ }^{57,58}$. The use of plastic wrap on the NB's body and head minimizes heat loss by evaporation and convection ${ }^{59}$. This product decreases the risk of hypothermia from 21 to $46 \%{ }^{60}$.

The efficacy of using a polyethylene bag was also evaluated during the procedures. The use of sterile polyethylene drape showed to improve the maintenance of rectal temperature, as well as prevent hypothermia during umbilical catheter insertion when compared to the use of cotton fenestrated surgical drape ${ }^{16}$.

Other strategies have also been tested and have been recommended to contribute to thermal stability and reduction of hypothermia, such as placing a newspaper sheet between two preheated cotton sheets ${ }^{29}$, the use of thermal blanket added to the radiant-heat cradle ${ }^{23}$, and the use of a conductive thermal mattress from six hours of life ${ }^{26}$. On the other hand, it was observed that the use of a thermostable mattress associated with the use of a polyethylene bag in the body might increase the risk of hyperthermia in NU admission ${ }^{17}$.

In a Cochrane review, there were found 25 studies that presented interventions applied up to 10 minutes after birth to prevent hypothermia in PTNBs and/ or low weight NBs. The authors revealed evidence of moderate quality to recommend the use of plastic wraps or bags, especially in PTNBs with less than 30 weeks of GA, because this practice improved the temperature in NU admission ${ }^{61}$. In contrast, there is insufficient evidence to suggest that this practice reduces neonatal mortality or other important morbidities. The authors also emphasize that, despite reducing the risk of hypothermia, the use of thermal mattresses and the practice of skin-to-skin contact are based on small studies, and do not provide sufficient evidence to support official recommendations. According to them, caution should be taken when adopting simultaneous methods to increase temperature, in order to avoid overheating of the neonate ${ }^{61}$. Hyperthermia stimulates the release of excitatory neurotransmitters in the brain, causing convulsion. It also worsens brain damage in asphyxiated babies $^{62}$.

As for the ideal weight to transfer the NB from the incubator to the cradle, it was demonstrated that babies with 1,500 to 1,600 grams did not present differences in thermal regulation, energy expenditure, or weight gain ${ }^{25}$. A Cochrane review conducted in 2011 provides evidence that stable NBs, weighing 1,600 grams, can be safely transferred to a cradle with no interference to thermal regulation or weight gain. It also reinforces that they present better thermal stability, greater weight gain and shorter hospitalization period $^{63}$. 
Based on the studies found on thermoregulation, it is noteworthy that only the use of wraps and plastic bags immediately after birth, as well as the transfer of NBs with weight from 1,600 grams from the incubator to the cradle present robust evidence to support the care practice.

\section{Use of emollients}

In this category, seven studies were found that address the use of emollients in the NB skin. The skin is formed by the epidermis, dermis and subcutaneous tissue. The outer layer of the epidermis, the stratum corneum, acts as an epidermal barrier, preventing fluid loss through the skin and the invasion of agents from the external environment ${ }^{64}$. The epidermal barrier starts to develop in the fetus at 24 weeks' gestation and its histological development is completed at 34 weeks' gestation, but functionally it continues its development during the baby's first year of life $3,57,64,65$. PTNBs have impaired epidermal barrier function, which makes them susceptible to TEWL and infection. The use of emollients seems to improve the epidermal barrier function and protect it from these risks.

In a systematic literature review designed to identify studies on the efficacy of emollient therapy, it was concluded that the topical use of these products in PTNBs significantly contributed to the reduction of hospital infection and neonatal mortality, in addition to increasing the daily weight gain ${ }^{66}$.

A study on the evaluation of the effect of the use of emollients based on petrolate or sunflower oil on skin conditions and on the risk of infection in PTNBs demonstrated that emollients maintain the integrity of the skin and contribute to the prevention of infection. However, to optimize the benefits of these products, the authors recommend that their use be initiated immediately after birth when the skin is still intact ${ }^{30}$. In contrast, it was observed that the use of sunflower seed oil might delay the maturation of the skin barrier in PTNBs ${ }^{33}$. However, this study was carried out with a small sample of NBs and further studies are necessary to support this finding.

The application of coconut oil twice a day at PTNBs, from birth to 28 days of life, was useful in weight gain, maintaining skin integrity and reducing the risk of bloodstream infection ${ }^{34}$. The same product, when applied on very low-weight NBs, improves skin condition, reduces TEWL and does not increase skin colonization $^{35}$. It was also observed that this product does not cause any adverse effect on PTNBs with less than 30 weeks of $\mathrm{GA}^{36}$.

Analyzing the studies, it was observed that the use of emollients in PTNBs has shown excellent results in terms of weight gain, maintenance of skin integrity, prevention of infection and atopic dermatitis. On the other hand, there is a risk of increased TEWL and delayed maturation of the epidermal barrier ${ }^{33}$. It is important to emphasize that the tested product based on petrolate is not available for use in Brazil, however sunflower seed, mineral and coconut oils are low-cost options and easily found in the country.

A Cochrane review evaluated the topical application of emollients on the prevention of infection in PTNBs. The authors identified 18 publications, but the data did not provide evidence that invasive infection or death can be prevented by their use in $\mathrm{PTNBs}^{67}$. According to the authors, the use of emollient ointment in NBs, weighing less than 750 grams may increase the risk of coagulase-negative staphylococcal infections in high-income countries. In low- and middle-income countries, although there is some evidence that the use of topical vegetable oil can increase weight gain, there is no substantial evidence that it prevents infection or reduces mortality. For this reason, it is recommended to perform more pragmatic RCTs in order to improve the quality of evidence to support this practice ${ }^{67}$.

Partial results of a study that is under development in China with a sample of $428 \mathrm{NBs}$ have demonstrated that topical sunflower seed oil therapy in NBs $<34$ weeks of GA before 72 hours of life, when compared to mineral oil or no use of any product, has been shown to be superior and has improved skin condition of PTNBs without increasing the risk of infection ${ }^{68}$. Although there is still no high-quality evidence on the use of emollients in PTNBs, the Association of Women's Health, Obstetric and Neonatal Nurses (AWHONN) recommends their use, but advises caution on signs of systemic infection during the use of these products in NBs weighing less than $750 \mathrm{~g}^{69}$.

\section{Antiseptics}

In this category, four studies were found that address the use of antiseptics in the NB skin. 
The NBs hospitalized in NUs are susceptible to infections related to health care. Therefore, the use of topical antiseptics before the performance of invasive procedures is essential to prevent them ${ }^{70}$. On the other hand, the anatomical and physiological alterations of the NB's skin, especially the PTNB's, put this patient at risk of greater absorption of toxic products through the skin and of chemical burns by the use of these substances. In this regard, the choice of antiseptic becomes a dilemma for the neonatal team ${ }^{69,70}$.

The studies included in this review demonstrate that the identification of the ideal product that acts as an aseptic without causing adverse effects is relevant and at the same time, concerning topics for researchers. Chlorhexidine gluconate (CG) is a broad-spectrum antiseptic and is the agent of choice in skin preparation before invasive procedures are performed. It is available in aqueous or alcohol-based solutions at concentrations of $0.25,0.5,1,2$ and $4 \%{ }^{70,71}$.

The use of $\mathrm{CG}$ in $1 \%$ aqueous solution versus iodopovidone (PVP-I) at 10\%, as topical antiseptics in $\mathrm{NBs}$ with weight greater than or equal to 1,500 grams, demonstrated that CG is superior to PVP-I in reducing blood culture contamination rates and that no reaction was observed on skin with the use of these antiseptics ${ }^{37}$. A multicenter study conducted in Ireland also found no differences in bloodstream infection rates, as well as skin reactions, when comparing the use of 2\% CG in alcoholic solution with 10\% PVP-I in aqueous solution, in skin asepsis of NBs with GA < 31 weeks. However, the authors reported that $7.7 \%$ of the NBs allocated to the PVP-I group presented thyroid dysfunction ${ }^{38}$. This finding was confirmed when researchers identified that PVP-I is associated with an elevated risk of transient hypothyroidism in PTNBs, due to its high absorption through the skin, and it should be used with caution and vigilance in this population $^{72}$.

A retrospective cohort study showed a statistically significant reduction of skin lesions in PTNBs under 30 weeks of GA with the use of $0.2 \%$ chlorhexidine acetate, without increasing the risk of infection ${ }^{39}$. It was reinforced that the alcoholic solutions of chlorhexidine are more associated with adverse reactions, such as burns and dermatitis in babies' skin, with a higher degree of severity in PTNBs and extreme low-weight $\mathrm{NBs}^{71}$.
Regarding the effects of bathing with antiseptic on reducing the incidence of neonatal sepsis, the use of chlorhexidine has been shown effective. The authors emphasize that this may be an easy and inexpensive option for countries with high neonatal mortality rates due to sepsis ${ }^{40}$. On the other hand, in a systematic Cochrane review, the authors concluded that the quality of evidence to support the cleaning of the NB's skin with chlorhexidine at birth is low and that it may increase the risk of hypothermia ${ }^{73}$.

Studies on the use of antiseptics show that there is no evidence of high quality to indicate the choice of an ideal product, which acts effectively in asepsis while providing safety in the prevention of skin lesions in hospitalized patients.

\section{Oxygenation devices}

In this category, two articles were found that address care with oxygenation devices.

The NB admitted to a NU requires several clinical devices to ensure its survival. On the other hand, at the same time that they contribute to care, they also put the patient's skin integrity at risk. The use of devices can cause injury by pressure, friction and removal of adhesive ${ }^{3}$. A Cochrane review intended to compare the effects of different methods of endotracheal tube fixation in NBs. The studies presented low methodological quality and a significant risk of bias. Accidental extubation was the most commonly found result. The authors concluded that there is no evidence to recommend a safe and effective method to fix the tube in $\mathrm{NBs}^{74}$.

Although they may cause injury related to adhesive removal, critical care devices such as endotracheal tubes should remain firmly fixed. The use of skin barrier dressings on patch between the skin and the tube fixation adhesive may detach and cause accidental extubation, compromising the patient's safety. For this reason, these products as well as low-adhesive tapes are contraindicated ${ }^{74-76}$.

Regarding the pressure lesion, more than $90 \%$ in PTNBs are related to the use of devices ${ }^{1}$. Based on the studies included in this review, it can be seen that the use of continuous positive airway pressure (CPAP) may favor the occurrence of these lesions. The incidence of nasal injury has been significantly reduced with the use of high flow cannula compared to CPAP, especially in 
NBs under 28 weeks of age. However, in this study, two skin protectors evaluated during the use of the devices were not associated with the reduction of nasal lesion in $\mathrm{NBs}$ in $\mathrm{CPAP}^{44}$.

Different nasal interfaces were compared during the use of CPAP in NBs with a weight of less than 1,500 grams. The researchers identified significantly smaller erythema and lesion in the group in which nasal prong and mask were alternated every four hours. The authors also observed that the risk for injury increases as the therapy time extends for more than three days. They emphasize that the use of skin barriers, respiratory physiotherapy, clinical experience of nurses and skin evaluation are strategies that should be considered in the prevention of injury related to the use of this device ${ }^{45}$.

The use of a skin barrier (hydrocolloid) during CPAP treatment in PTNBs and low-weight NBs has been shown to reduce the incidence of nasal injury. The authors concluded that this strategy can be effective in the prevention of injury related to $\mathrm{CPAP}^{77}$. The use of dressing under the devices allows the formation of a skin barrier between the skin and the device, reducing pressure and shear ${ }^{78}$. In contrast, another study ${ }^{44}$ showed no reduction in lesions with use of a skin protector, however, a group without nasal protection was not included, which may indicate bias.

Based on the studies on oxygenation included in this review, it can be observed that there is no evidence of quality that supports an adequate method for endotracheal tube fixation, but the use of a protective barrier is contraindicated given the risk of extubation. The alternation between nasal prongs and masks and the use of a protective barrier between the skin and the device are strategies that can contribute to the prevention of injuries related to the use of CPAP.

\section{Venous access}

In this category, only one study was found that addresses the issue of venous access. The use of medications and intravenous solutions are essential for the treatment of hospitalized NBs, but it exposes them to the risk of lesions by infiltration and extravasation. These lesions occur by inadvertently administering medication or fluid to the surrounding tissue instead of the blood vessel, and are secondary to the displacement of the intravenous catheter or the chemical composition of some medications. Irritant and vesicant intravenous drugs, when infused outside the vessel, cause vein irritation, pain and chemical phlebitis at the injection location and may evolve to deep lesion. The infiltration will only be a true extravasation if the offending agent is vesicant. However, both are destructive, causing injury to the fragile skin of the $\mathrm{NB}^{79,80}$.

Because of the consequences they can bring to the $\mathrm{NB}$, these lesions should be prevented and some measures should be taken, such as prioritizing smaller-caliber polyurethane catheters for peripheral punctures, because they are more flexible, cause less irritation of the cannula in the vessel wall, reduce the risk of mechanical phlebitis and infectious complications ${ }^{81}$; avoiding punctures in areas of flexion, because they are difficult to fix and may cause detachment of the dressing and displacement of the catheter during mobilization, interfering with the maintenance of venous access ${ }^{69,80}$; stabilization of the catheter should be performed aseptically, preferably with semipermeable transparent membrane, allowing constant monitoring and evaluation of the insertion site and surrounding area for signs of inflammation, infiltration and/or leakage $\mathrm{e}^{69,81}$.

Irritant drugs $(\mathrm{pH}<5.0)$, vesicant drugs $(\mathrm{pH}>9.0)$ and solutions with osmolarity above $900 \mathrm{mOsm} / \mathrm{L}$ should not be infused into a peripheral venous catheter, as they increase the risk of chemical phlebitis. The use of an electric pump is essential to control the infusion flow precisely. These devices have safety features such as occlusion alarm and free antiflow protection, which alert the professional about possible problems that may compromise venous access and the patient safety ${ }^{80,81}$.

Newborns present greater difficulty for venipuncture and greater fragility of the vessels, for this reason the routine replacement of the venous access is contraindicated, it is recommended to change it only when it is clinically indicated ${ }^{82}$. The venous catheter is an invasive device and can cause infection of the bloodstream, so it should be removed when intravenous therapy is no longer indicated ${ }^{80,81}$.

Regarding the use of a peripherally inserted central catheter (PICC), the insertion of this device through the axillary vein in PTNBs resulted in a significant reduction of complications such as edema, inflammation, obstruction and infection, when compared to other insertion sites ${ }^{46}$. In contrast, a study not included in 
this review showed that the insertion of this catheter in the veins of the scalp is also feasible and does not result in increased complications ${ }^{83}$. A Cochrane review found that the use of PICC favors the entry of nutrients into the NB receiving parenteral nutrition (PN). In addition, PICC reduces the need for venipuncture and consequently, pain. No evidence was found to support the increased risk of adverse events by the use of this catheter ${ }^{84}$.

Regarding the use of antimicrobial dressings in venous access, a Cochrane review assessed whether their use is safe and effective in reducing central venous catheter-related infection in $\mathrm{NBs}^{85}$. The study showed that chlorhexidine dressing reduced catheter colonization, but resulted in a higher risk of dermatitis development in PTNBs. Alginate and silver dressing do not show significant difference in infection rate, but the evidence is insufficient to support the use of alginate and silver dressing in $\mathrm{NB}^{85}$.

Based on studies on the use of venous access included in this review, it was observed that the evidence supports the replacement of the peripheral catheter only when necessary and the preference for the use of PICC for infusion of $\mathrm{PN}$ or other solutions that require prolonged treatment. Regarding the use of antimicrobial dressings to prevent infection, there is a lack of quality studies to suggest this practice. It is noteworthy that the effects of the use of chemical products on the NB skin are not yet well understood and should be used with caution, especially in PTNBs, which have immature skin barrier function.

\section{Cleaning of the umbilical stump}

In this category, three studies that address the care of the umbilical stump were found.

The recently-cut umbilical cord is a site of bacterial colonization and can cause infection and death of the NB. However, hygiene practices, especially in places where hygiene conditions are poor, potentially contribute to preventing these risks ${ }^{86}$.

A study demonstrated that the topical use of chlorhexidine in the umbilical cord decreased the time to fall, as well as prevented sepsis in $\mathrm{PTNBs}^{41}$. One year later, when analyzing the study data again, the authors also observed that the topical use of chlorhexidine in the umbilical stump contributes to the decrease in neonatal mortality ${ }^{42}$.
The application of alcohol as well as the cleaning with water only did not show difference regarding hydration, temperature, $\mathrm{pH}$ and bacterial flora of the umbilical stump. However, the water provided a reduction in the time to fall off $^{43}$.In a Cochrane systematic review, the authors concluded that in the hospital environment of developing countries, there is moderate evidence to support the use of chlorhexidine in the NB umbilical cord to reduce the risk of infection, but there is still uncertainty about its effect on neonatal mortality. In developed countries there is no evidence of quality that indicates this benefit, so it is recommended to keep the stump clean and dry ${ }^{73}$.

Based on studies on umbilical cord care included in this review, there is moderate evidence that supports the use of chlorhexidine to prevent infection in developing countries, but there is no recommendation on the appropriate concentration or diluted solution to be used. In developed countries, it is recommended to keep the place clean and dry. In Brazil, the Ministry of Health advises the use of $70 \%$ ethyl alcohol or $0.5 \%$ alcoholic chlorhexidine solution for sanitizing the umbilical stump in term $\mathrm{NB}$, and aqueous chlorhexidine solution in extreme PTNBs, in order to protect it against infection ${ }^{87}$.

\section{General care}

Five studies were found that address general NB care. In this category will be discussed bathing, the use of skin care products, phototherapy and diaper dermatitis, subjects that were scarcely found in this review. In relation to bathing, a study showed that when it is performed in the direction of the trunk to the head, it allowed a better and faster recovery of body temperature. According to the authors, these findings are attributed to the shorter period in which the NB remained with the head wet, contributing to the reduction of heat loss by evaporation ${ }^{48}$.

Bathing is a procedure that may not be pleasant for the newborn ${ }^{88}$. Less frequent baths reduce the need for handling and the chances of stress by cold, provide better physiological and behavioral stability of $\mathrm{PTNB}^{69}$. On the other hand, the technique of wrapping the NB in a soft towel and immersing him in the bathtub with water up to the region below the shoulders contributed to reduce stress, when compared to the bath under tap ${ }^{49}$.

It is noteworthy that the swaddle bath is a practice recommended by the Ministry of Health of Brazil 
from the kangaroo care Method, because it provides gentle and frequent stimulation to thermal, tactile and proprioceptive receptors, offering powerful stimuli that can compete with pain and stress, reducing the risk of physiological imbalance in $\mathrm{NBs}^{56}$. On the other hand, tap baths can lead to scald burns by in young children, due to the difficulty in controlling the water temperature, which can quickly become hot, as well as the lack of motor skills to come out from under the hot water ${ }^{89}$.

Still in relation to the hygiene and hydration of the NB, it was found a study about the application of a specific line of skin care products, in PTNBs hospitalized in a NU, including cleaning solutions, hydrating and cream of zinc oxide. The products did not significantly improve skin condition, perineal erythema or pain ${ }^{51}$.

The use of products in NBs should be carried out with caution. Topical application of some detergents and chemical agents may compromise the skin barrier and facilitate the development of eczema or atopic dermatitis. Thus, the integrity of the skin must be preserved, toxicity prevented and exposure to harmful chemical agents must be avoided ${ }^{90}$.

As for phototherapy, only one study was found and demonstrated that the skin rashes presented during treatment are macules, papules and maculopapular eruptions. The authors found no differences in the incidence or extent of eruptions when different phototherapy equipment was used ${ }^{47}$.

Regarding diaper dermatitis, the barrier cream composed of $40 \%$ zinc oxide with formulation of cod liver oil, as well as human milk, showed similar periods in clinical improvement of the lesion of diaper dermatitis in PTNBs and term NBs hospitalized in NU. However, the barrier cream provided a better skin score after injury, showing that the cream offers more effective results than human breast milk in the treatment of diaper dermatitis ${ }^{50}$. Products based on zinc oxide are the most widely used in the prevention of this lesion. They are not absorbed by the skin, repel fluids and have astringent, antiseptic and antibacterial properties ${ }^{91}$.

Prevention is the key to the care for diaper dermatitis. The frequency of changing diapers should be increased, the perineal area should be gently cleaned, a product providing barrier protection should be applied, and the site should be evaluated in order to identify risks of injury ${ }^{92}$.
The general care studies included in this review demonstrate that swaddle bathing is a procedure that can be safely replicated, tap bathing causes stress and can cause burning, there is no evidence to ensure the use of care products in the PTNB's skin, no recommendations for care during phototherapy were found and the use of zinc oxide barrier cream is safe, provides skin protection and prevents dermatitis in the diaper area.

In this review, the authors drawn attention to practices that were not found during the database search, such as the use of predictive injury risk scales, management of the incubator humidification, prevention of injury by pressure, fixation of devices, use of intravenous drugs, administration of intramuscular medication, umbilical catheterization, collection of tests and prevention of adhesive-related injury, demonstrating that these are gaps in the knowledge on the subject.

\section{CONCLUSION}

This study identified different strategies to support health professionals, especially the nursing staff, in the care of the NB's skin. It is noteworthy that thermoregulation was the most studied topic, although the use of emollients, antiseptics and care of the umbilical stump also stood out. This demonstrates that the practices that contribute to the maintenance of the NB's body temperature since the first minutes of life, are fundamental for the child to reach homeostasis, which is a constant concern of professionals who work in neonatal care.

The literature has shown that the prevention of skin lesions is a relevant and current subject; on the other hand, it is observed that there is scarcity of robust evidence that can safely sustain care practices for the NB and that the scientific evidence found is insufficient to encompass the universe of the subject.

The need to promote clinical research related to the care of the NB's skin in Brazil is highlighted, considering the importance of the subject and the lack of evidence to support the practices.

Based on the results obtained in this review, it can be concluded that the newborn's skin care practices require a scientific basis, which is essential to improve and ensure the assistance provided by the neonatal staff. Randomized clinical trial (RCT) requires time, commitment on the 
part of researchers, availability of resources, and should be undertaken with methodological rigor in a constant manner, addressing all the issues involved in the topic.

\section{FUNDING}

This research was supported by the Coordination for the Improvement of Higher Education Personnel - Brazil (CAPES) - Financing Code 001.
AUTHORS' CONTRIBUTION

\section{Conceptualization, Santos SV; Ramos FRS and Costa} R; Methodology, Santos SV; Ramos FRS; Costa R and Batalha LMC; Investigation, Santos SV; Ramos FRS and Costa R; Writing - Original Draft, Santos SV; Writing Review and Editing, Santos SV; Ramos FRS; Costa R and Batalha LMC; Financing Acquisition, Ramos FRS and Costa R; Resources, Santos SV; Ramos FRS and Costa R; Supervision, Ramos FRS; Costa R and Batalha LMC.

\section{REFERENCES}

1. Visscher MO, Taylor T. Pressure ulcer in the hospitalized neonate: rates and risk factors. Sci Rep. 2014;4(7429): 1-6. https://doi.org/10.1038/srep07429

2. Chaves ACF, Santos AP, Ataíde KMN, Cunha KJB. Care and maintenance of premature neonate skin integrity. J Nurs UFPE on line. 2019;13(2):378-84.

3. Cousins Y. Wound care considerations in neonates. Nursing Stand. 2014;28(46):61-70. https://doi. org/10.7748/ns.28.46.61.e8402

4. Migoto MT, Souza SNDH, Rossetto EG. Lesões de pele em bebês internados em uma unidade neonatal: estudo observacional. Online Braz J Nur. 2013;12(2):377-92.

5. Faria TF, Kamada I. Skin injuries in newborns in neonatal intensive care. Enferm Glob. 2017;17(1):211-36. https:// doi.org/10.6018/eglobal.17.1.273671

6. Santos SV, Costa R. Treatment of skin lesions in newborn children: meeting the needs of nursing staff. Rev EsC Enferm USP. 2014;48(6):985-92. https://doi. org/10.1590/S0080-623420140000700004

7. Santos SV, Costa R. Prevention of newborn skin lesions: knowledge of the nursing team. Texto-Contexto Enferm. 2015:24(3):731-9. https://doi.org/10.1590/010407072015011230014

8. Rumbo-Prieto JM, Romero-Martín M, Bellido-Guerrero D, Arantón-Areosa L, Raña-Lama CD, Palomar-Llatas F. Evaluación de las evidencias y calidad de las guías de práctica clínica sobre deterioro de la integridad cutánea: úlceras y heridas crónicas. Anales Sis San Navarra 2016;39(3):405-15.

9. Mccune SK, Mulugeta YA. Regulatory science needs for neonates: a call for neonatal community collaboration and innovation. Front Pediatr. 2014;2(135):1-3. https:// doi.org/10.3389/fped.2014.00135

10. Coppini R, Simons SHP, Mugelli A, Allegaert K. Clinical research in neonates and infants: Challenges and perspectives. Pharmacol Res. 2016;108:80-7. https:// doi.org/10.1016/j.phrs.2016.04.025

11. Mendes KDS, Silveira RCCP, Galvão CM. Integrative literature review: a research method to incorporate evidence in health care and nursing. Texto-Contexto Enferm. 2008;17(4):758-64. https://doi.org/10.1590/ S0104-07072008000400018

12. Joanna Briggs Institute - JBI. Reviewers' manual [Internet]. 2014 [cited 2018 Nov 08]. Available from: https:// nursing.Isuhsc.edu/JBI/docs/ReviewersManuals/ Mixed-Methods.pdf

13. Moher D, Liberati A, Tetzlaff J, Altman DG. PRISMA Group. Preferred reporting items for systematic reviews and meta-analyses: The PRISMA statement. Plos Med. 2009;6(7):e1000097. https://doi.org/10.1371/journal. pmed.1000097

14. Phillips B, Ball C, Sackett D, Badenoch D, Straus S, Haynes $B$, et al. Oxford Centre for Evidence-based Medicine. Levels of evidence [Internet]. Oxford: CEBM; 2009 [cited 2017 Jul 02]. Available from: https://www.cebm. net/2009/06/oxford-centre-evidence-based-medicinelevels-evidence-march-2009/

15. Mathew B, Lakshminrusimha S, Sengupta S, Carrion V. Randomized controlled trial of vinyl bags versus thermal mattress to prevent hypothermia in extremely lowgestational-age infants. Am J Perinatol. 2013;30(4):31722. https://doi.org/10.1055/s-0032-1324700

16. Nuntnarumit P, Swatesutipun B, Udomsubpayakul U, Thanacharoenpipat P. A randomized controlled trial of plastic drape for prevention of hypothermia during umbilical catheterization. Am J Perinatol. 2013;30(10):83942. https://doi.org/10.1055/s-0033-1333670

17. 17. Mccarthy LK, Molloy EJ, Twomey AR, Murphy JFA, O'Donnell CPF. A randomized trial of exothermic mattresses for preterm newborns in polyethylene bags. Pediatrics. 2013;132(1):135-41. https://doi. org/10.1542/peds.2013-0279 
18. Leadford AE, Warren JB, Manasyan A, Chomba E, Salas $A A$, Schelonka $R$, et al. Plastic bags for prevention of hypothermia in preterm and low birth weight infants. Pediatrics. 2013;132(1):128-34. https://doi. org/10.1542/peds.2012-2030

19. Belsches, TC, Tilly AE, Miller TR, Kambeyanda RH, Leadford A, Manasyan A, et al. Randomized trial of plastic bags to prevent term neonatal hypothermia in a resource-poor setting. Pediatrics. 2013;132(3):656-61. https://doi.org/10.1542/peds.2013-0172

20. Nimbalkar SM, Patel VK, Patel DV, Nimbalkar AS, Sethi A, Phatak A. Effect of early skin-to-skin contact following normal delivery on incidence of hypothermia in neonates more than $1800 \mathrm{~g}$ : randomized control trial. J Perinatol. 2014;34(5):364-8. https://doi.org/10.1038/jp.2014.15

21. Çağlar S, Gözen D, Ince Z. Heat loss prevention (help) after birth in preterm infants using vinyl isolation bag or polyethylene wrap. JOGNN Nurs. 2014;43(2):216-23. https://doi.org/10.1111/1552-6909.12291

22. Doglioni N, Cavallin F, Mardegan V, Palatron S, Filippone M, Vecchiato L, et al. Total body polyethylene wraps for preventing hypothermia in preterm infants: a randomized trial. J Pediatr. 2014;165(2):261-6. https:// doi.org/10.1016/j.jpeds.2014.04.010

23. Hsu KH, Chiang MC, Lin SW, Lin JJ, Wang YC, Lien R. Thermal Blanket to Improve Thermoregulation in Preterm Infants: A Randomized Controlled Trial. Pediatr Crit Care Med. 2015;16(7):637-43. https://doi. org/10.1097/PCC.0000000000000447

24. Reilly MC, Vohra S, Rac VE, Dunn M, Ferrelli K, Kiss K, et al. Randomized trial of occlusive wrap for heat loss prevention in preterm infants. J Pediatr. 2015;166(2):2628. https://doi.org/10.1016/j.jpeds.2014.09.068

25. Berger I, Marom R, Mimouni F, Kopelovich R, Dollberg $\mathrm{S}$. Weight at weaning of preterm infants from incubator to bassinet: a randomized clinical trial. Am J Perinatol. 2014;31(6):535-40. https://doi. org/10.1055/s-0033-1354563

26. Bhat SR, Meng NF, Kumar K, Nagesh KN, Kawale A, Bhutani VK. Keeping babies warm: a non-inferiority trial of a conductive thermal mattress. Arch Dis Child Fetal Neonatal. 2015;100(4):309-12. https://doi.org/10.1136/ archdischild-2014-306269

27. Shafie H, Zakaria SZS, Adli A, Shareena I, Rohana J. Polyethylene versus cotton cap as an adjunct to body wrap in preterm infants. Pediatr Int. 2017;59(7):776-80. https://doi.org/10.1111/ped.13285

28. Hu XJ, Wang L, Zheng R, LV T, Zhang Y, Cao Y, et al. Using polyethylene plastic bag to prevent moderate hypothermia during transport in very low birth weight infants: a randomized trial. J Perinatol. 2018;38(4):332-6. https://doi.org/10.1038/s41372-017-0028-0

29. Agrawal N, Das K, Patwal P, Pandita N, Gupta A. Wrapping newborn infants in cloth and newspaper after delivery led to higher temperatures on arrival at the neonatal intensive care unit. Acta Paediatr. 2018;107(8):1335-8. https://doi.org/10.1111/apa.14211

30. Darmstadt G, Ahmed S, Ahmed ASMN, Saha S. Mechanism for prevention of infection in preterm neonates by topical emollients: a randomized, controlled clinical trial. Pediatr Infect Dis J. 2014;33(11):1124-7. https://doi. org/10.1097/INF.0000000000000423

31. Horimukai K, Morita K, Narita M, Kondo M, Kitazawa $H$, Nozaki M. Application of moisturizer to neonates prevents development of atopic dermatitis. J Allergy Clin Immunol. 2014;134(4):824-30. https://doi. org/10.1016/j.jaci.2014.07.060

32. Erdemir A, Kahramaner Z, Yuksel Y, Cosar H, Turkoglu E, Sutcuoglu S, et al. The effect of topical ointment on neonatal sepsis in preterm infants. J Matern Fetal Neonatal Med. 2014;28(1):33-6. https://doi.org/10.310 9/14767058.2014.900037

33. Kanti V, Grande C, Stroux A, Bührer C, Blume-Peytavi U, Garcia Bartels N. Influence of sunflower seed oil on the skin barrier function of preterm infants: a randomized controlled trial. Dermatology. 2014;229(3):230-9. https://doi.org/10.1159/000363380

34. Salam RA, Darmstadt GL, Bhutta ZA. Effect of emollient therapy on clinical outcomes in preterm neonates in Pakistan: a randomised controlled trial. Arch Dis Child Fetal Neonatal. 2015;100(3):210-5. https://doi. org/10.1136/archdischild-2014-307157

35. Nangia S, Paul VK, Deorari AK, Sreenivas V, Agarwal R, Chawla D. Topical Oil Application and Trans-Epidermal Water Loss in Preterm Very Low Birth Weight Infants-A Randomized Trial. J Trop Pediatr. 2015;61(6):414-20. https://doi.org/10.1093/tropej/fmv049

36. Strunk T, Pupala S, Hibbert J, Doherty D, Patole S. Topical Coconut Oil in Very Preterm Infants: An Open-Label Randomised Controlled Trial. Neonatol. 2018;113(2):14651. https://doi.org/10.1159/000480538

37. Nuntnarumit $P$, Sangsuksawang N. A randomized controlled trial of $1 \%$ aqueous chlorhexidine gluconate compared with $10 \%$ povidone-iodine for topical antiseptic in neonates: effects on blood culture contamination rates. Infect Control Hosp Epidemiol. 2013;34(4):430-2. https://doi.org/10.1086/669863

38. Kieran EA, O'Sullivan A, Miletin J, Twomey AR, Knowles SJ, O'Donnell CPF. 2\% chlorhexidine-70\% isopropyl alcohol versus $10 \%$ povidone-iodine for insertion site cleaning before central line insertion in preterm infants: a randomised trial. Arch Dis Child Fetal Neonatal. 2018;103(2):101-6. https:/doi.org/10.1136/ archdischild-2016-312193

39. Janssen LMA, Tostmann A, Hopman J, Liem KD. 0.2\% chlorhexidine acetate as skin disinfectant prevents skin lesions in extremely preterm infants: a preliminary report. Arch dis child fetal neonatal ed. 2018;103(2):97-100. https://doi.org/10.1136/archdischild-2017-312694 
40. Gupta B, Vaswani ND, Sharma D, Chaudhary U, Lekhwani S. Evaluation of efficacy of skin cleansing with chlorhexidine in prevention of neonatal nosocomial sepsis - a randomized controlled trial. J Matern Fetal Neonatal Med. 2016;29(2):242-7. https://doi.org/10.31 $09 / 14767058.2014 .996126$

41. Gathwala G, Sharma D, Bhakhri BK. Effect of topical application of chlorhexidine for umbilical cord care in comparison with conventional dry cord care on the risk of neonatal sepsis: a randomized controlled trial. J Trop Pediatr. 2013;59(3):209-13. https://doi.org/10.1093/ tropej/fmt003

42. Sharma D, Gathwala G. Impact of chlorhexidine cleansing of the umbilical cord on cord separation time and neonatal mortality in comparison to dry cord care - a nursery-based randomized controlled trial. J Matern Fetal Neonatal Med. 2014;27(12):1262-5. https://doi.or g/10.3109/14767058.2013.854325

43. Ahn Y, Sohn M, Jun Y, Lee E, Lee S. Two methods of cord care in high-risk newborns: their effects on hydration, temperature, $\mathrm{pH}$, and floras of the cord area. J Child Health Care. 2015;19(1):118-29. https://doi. org/10.1177/1367493513503580

44. Collins CL, Barfield C, Horne RSC, Davis PG. A comparison of nasal trauma in preterm infants extubated to either heated humidified high-flow nasal cannulae or nasal continuous positive airway pressure. Eur J Pediatr. 2014;173(2):181-6. https://doi.org/10.1007/s00431013-2139-8

45. Newnam KM, McGrath JM, Salyer J, Estes T, Jallo N, Bass WT. A comparative effectiveness study of continuous positive airway pressure-related skin breakdown when using different nasal interfaces in the extremely low birth weight neonate. Appl Nurs Res. 2015;28(1):36-41. https://doi.org/10.1016/j.apnr.2014.05.005

46. Panagiotounakou P, Antonogeorgos G, Gounari E, Papadakis S, Labadaridis J, Gounaris AK. TI: Peripherally inserted central venous catheters: frequency of complications in premature newborn depends on the insertion site. J Perinatol. 2014;34(6):461-3. https://doi. org/10.1038/jp.2014.36

47. Surmeli-Onay O, Ayse Korkmaz A, Yigit S, Yurdakok M. Phototherapy rash in newborn infants: does it differ between conventional and light emitting diode phototherapy? Pediatr Dermatol. 2013;30(5):529-33. https://doi.org/10.1111/pde.12083

48. So HS, You MA, Mun JY, Hwang MJ, Kim HK, Pyeon SJ, et al. Effect of trunk-to-head bathing on physiological responses in newborns. J Obstetric Gynecologic Neonatal Nurs: JOGNN. 2014;43(6):742-51. https://doi. org/10.1111/1552-6909.12496

49. Paran M, Edraki M, Montaseri S, Razavi Nejad MA. Comparing the effects of swaddle and conventional bathing methods on behavioral responses in preterm neonates. Iran J Neonatol. 2016;7(4):35-40. https://doi. org/10.22038/ijn.2016.7778
50. Gozen D, Caglar S, Bayraktar S, Atici F. Diaper dermatitis care of newborns human breast milk or barrier cream. J Clin Nurs. 2014;23(3-4):515-23. https://doi.org/10.1111/ jocn.12047

51. Young DL, Chakravarthy D, Drower E, Reyna, R. Skin care product evaluation in a group of critically ill, premature neonates: a descriptive study. J Wound Ostomy Continence Nurs. 2014;41(6):519-27. https:// doi.org/10.1097/WON.0000000000000083

52. World Health Organization. Thermal protection of the newborn: A practical guide [Internet] 1997 [cited 2018 Dec 23]. Available from: https://www.who.int/maternal_ child_adolescent/documents/ws42097th/en/

53. Foster J, Psalia K, Kenner C. Maintaining the Heat on Neonatal Hypothermia in Developing Countries. Newborn Infants Nurs Rev. 2014;14(2):42-4. https://doi. org/10.1053/j.nainr.2014.03.004

54. Knobel RB. Thermal stability of the premature infant in neonatal intensive care. Newborn Infants Nurs Rev. 2014;14(2):72-6. https://doi.org/10.1053/j. nainr.2014.03.002

55. Kanodia P, Bora R, Gupta A. Kangaroo mother care-a cost effective and an alternate method to manage hypothermia in low birth weight babies for better clinical outcome. Value Health. 2016;19(7):A405. https://doi. org/10.1016/j.jval.2016.09.338

56. Brasil. Ministério da Saúde. Secretaria de Atenção à Saúde. Departamento de Ações Programáticas Estratégicas. Atenção humanizada ao Recém-Nascido: Método Canguru: manual técnico. 3 ed. Brasília: MS [Internet] 2017 [cited 2018 Dec 20] Available from: http://bvsms.saude.gov.br/bvs/publicacoes/atencao_ humanizada_metodo_canguru_manual_3ed.pdf

57. Ness MJ, Davis DMR, Carey WA. Neonatal skin care: a concise review. Int J Dermatol. 2013;52(1):14-22. https:// doi.org/10.1111/j.1365-4632.2012.05687.x

58. Knobel RB. Fetal and neonatal thermal physiology. Newborn Infants Nurs Rev. 2014;14(2):45-9. https://doi. org/10.1053/j.nainr.2014.03.003

59. Pinheiro JM, Furdon SA, Boynton S. Decreasing hypothermia during delivery room stabilization of preterm neonates. Pediatrics. 2014;133(1):218-26. https://doi.org/10.1542/peds.2013-1293

60. Oatley HK, Blencowe H, Lawn JE. The effect of coverings, including plastic bags and wraps, on mortality and morbidity in preterm and full-term neonates. J Perinatol. 2016;36 Suppl 1:83-9. https://doi.org/10.1038/ jp. 2016.35

61. Mccall EM, Alderdice F, Halliday HL, Vohra S, Johnston L. Interventions to prevent hypothermia at birth in preterm and/or low birth weight infants. Cochrane Database Syst Rev. 2018;2:CD004210. https://doi. org/10.1002/14651858.CD004210.pub5 
62. Brasil. Ministério da Saúde. Secretaria de Atenção à Saúde. Departamento de Ações Programáticas Estratégicas. Atenção à saúde do recém-nascido: guia para os profissionais de saúde. Cuidados com o recémnascido pré-termo. 4 (2 ed.) Brasília: MS. [Internet] 2014 [cited 2018 Dec 20] Available from: http://bvsms. saude.gov.br/bvs/publicacoes/atencao_saude_recem_ nascido_v4.pdf

63. New K, Flenady V, Davies MW. Transfer of preterm infants from incubator to open cot at lower versus higher body weight. Cochrane Database Syst Rev. 2011;9:CD004214. https://doi.org/10.1002/14651858.CD004214.pub4

64. Visscher MO, Adam R, Brink S, Odio M. Newborn infant skin: physiology, development, and care. Clin Dermatol. 2015;33(3):271-80. https://doi.org/10.1016/j. clindermatol.2014.12.003

65. King A, Balaji S, Keswani SG. Biology and Function of Fetal and Pediatric Skin. Facial Plast Surg Clin N Am. 2013;21(1):1-6. https://doi.org/10.1016\%2Fj. fsc. 2012.10 .001

66. Salam RA, Das JK, Darmstadt GL, Bhutta ZA. Emollient therapy for preterm newborn infants - evidence from the developing world. BMC Public Health. 2013;13Suppl 3:S31. https://doi.org/10.1186/1471-2458-13-S3-S31

67. Cleminson J, Mcguire W. Topical emollient for preventing infection in preterm infants. Cochrane Database Syst Rev. 2016;(1):CD001150. https://doi.org/10.1002/14651858. CD001150.pub3

68. Hu X, Zhang Y. Effect of topically applied sunflower seed oil in preterm infants. Pediatr Crit Care Med. 2014;15(4):144-5. https://doi.org/10.1097/01.pcc.0000449366.67893.84

69. Association of women's health, obstetric and neonatal nurses (AWHONN). Neonatal skin care: evidence-based clinical practical guideline. 3 ed. Washington: AWHONN. 2013.

70. Sathiyamurthy S, Banerjee J, Godambe SV. Antiseptic use in the neonatal intensive care unit - a dilemma in clinical practice: An evidence-based review. World J Clin Pediatr. 2016;5(2):159-71. https://doi.org/10.5409/ wjcp.v5.i2.159

71. Neri I, Ravaioli GM, Faldella G, Capretti MG, Arcuri S, Patrizi. Chlorhexidine-Induced Chemical Burns in Very Low Birth Weight Infants. J Pediatr. 2017;191:262-5. https://doi.org/10.1016/j.jpeds.2017.08.002

72. Pinsker JE, McBayne K, Edwards M, Jensen K, Crudo DF, Bauer AJ. Transient Hypothyroidism in Premature Infants After Short-term Topical Iodine Exposure: An Avoidable Risk? Pediatr Neonatol. 2013;54(2):128-31. https://doi. org/10.1016/j.pedneo.2012.10.005

73. Sinha A, Sazawal S, Pradhan A, Ramji S, Opiyo N. Chlorhexidine skin or cord care for prevention of mortality and infections in neonates. Cochrane Database Syst Rev. 2015;3:CD007835. https://doi.org/10.1002/14651858. CD007835.pub2
74. Lai M, Inglis GDT, Hose $K$, Jardine LA, Davies MW. Methods for securing endotracheal tubes in newborn infants. Cochrane Database Syst Rev. 2014;7:CD007805. https://doi.org/10.1002/14651858.CD007805.pub2

75. MurrayJS, Noonan C, QuigleyS, Curley MAQ. Medical devicerelated hospital-acquired pressure ulcers in children: an integrative review. J Pediatr Nurs. 2013;28(6):585-95. https://doi.org/10.1016/j.pedn.2013.05.004

76. Mcnichol L, Lund C, Rosen T, Gray M. Medical adhesives and patient safety: state of the science: consensus statements for the assessment, prevention, and treatment of adhesive-related skin injuries. J Wound Ostomy Continence Nurs. 2013;40(4):365-80. https:// doi.org/10.1097/WON.0b013e3182995516

77. Imbulana DI, Owen LS, Dawson JA, Davis PG, Manley BJ. The pronose study: a randomised controlled trial of a nasal barrier dressing to reduce injury in preterm infants receiving binasal non-invasive respiratory support. J Paediatr Child Health. 2018;54Suppl 1:82-3. https://doi. org/10.1111/jpc.13882_219

78. Flanagan KA. Noninvasive ventilation in premature neonates. Adv Neonatal Care. 2016;16(2):91-8. https:// doi.org/10.1097/ANC.0000000000000273

79. Beall, V. Hall B, Mulholland JT, Gephart SM. Neonatal Extravasation: an overview and algorithm for evidence-based treatment. Newborn Infant Nursing Reviews. 2013;13(4):18995. https://doi.org/10.1053/j.nainr.2013.09.001

80. Infusion Nurses Society. Infusion Therapy Standards of Practice. J Infus Nurs. [Internet] 2016 [cited 2018 Dec 29];39(1S):S1-156. Available at: http://ins.tizrapublisher. com/hai13r/

81. Brasil. Agência Nacional de Vigilância Sanitária - ANVISA. Medidas de Prevenção de Infecção Relacionada à Assistência à Saúde. Agência Nacional de Vigilância Sanitária, Brasília: Anvisa [Internet] 2017 [cited 2018 Dec 20]. Available from: http://portal.anvisa.gov.br/ documents/33852/3507912/Caderno+4+-+Medidas+d e+Prevenção+de+Infecção+Relacionada+à+Assistênci a+à+Saúde/a3f23dfb-2c54-4e64-881 c-fccf9220c373

82. Webster J, Osborne S, Rickard CM, New K. Clinicallyindicated replacement versus routine replacement of peripheralvenous catheters. Cochrane Database Syst Rev. 2015;8:CD007798. https://doi.org/10.1002/14651858. CD007798.pub4

83. Callejas A, Osiovich H, Ting JY. Use of peripherally inserted central catheters (PICC) via scalp veins in neonates. J Matern Fetal Neonatal Med. 2016;29(21):3434-8. https:// doi.org/10.3109/14767058.2016.1139567

84. Ainsworth S, Mcguire W. Percutaneous central venous catheters versus peripheral cannulae for delivery of parenteral nutrition in neonates. Cochrane Database Syst Rev. 2015;10:CD004219. https://doi. org/10.1002/14651858.CD004219.pub4 
85. Lai NM, Taylor JE, Tan K, Choo YM, Ahmad KA, Muhamad NA. Antimicrobial dressings for the prevention of catheter-related infections in newborn infants with central venous catheters. Cochrane Database Syst Rev. 2016;3:CD011082. https://doi.org/10.1002/14651858. CD011082.pub2

86. Coffey PS, Brown SC. Umbilical cord-care practices in low- and middle-income countries: a systematic review. BMC Pregnancy Childbirth. 2017;17(68):1-21. https:// doi.org/10.1186/s12884-017-1250-7

87. Brasil. Ministério da Saúde. Secretaria de Atenção à Saúde. Departamento de Ações Programáticas Estratégicas. Atenção à saúde do recém-nascido: guia para os profissionais de saúde. Cuidados gerais. 1 (2 ed.) Brasília: MS. [Internet] 2014 [cited 2018 Dec 20]. Available from: http://bvsms.saude.gov.br/bvs/ publicacoes/atencao_saude_recem_nascido_v1.pdf
88. Ruschel LM, Pedrini DB, Cunha MLC. Hipotermia e banho do recém-nascido nas primeiras horas de vida. Rev Gaúcha Enferm. 2018;39:e20170263. https://doi. org/10.1590/1983-1447.2018.20170263

89. Baggott K, Rabbitts A, Leahy NE, Bourke P, Yurt RW. Pediatric sink-bathing: a risk for scald burns. J Burn Care Res. 2013;34(6):639-643. https://doi.org/10.1097/ BCR.0b013e31827e5049

90. Kuller JM. Infant Skin Care Products: What Are the Issues? Adv Neonatal Care. 2016;16(S5):3-12. https:// doi.org/10.1097/ANC.0000000000000341

91. Esser M. Diaper Dermatitis: what do we do next? Adv Neonatal Care. 2016;16Suppl 5:21-5. https://doi. org/10.1097/ANC.0000000000000316

92. Stamatas GN, Tierney NK. Diaper dermatitis: Etiology, manifestations, prevention, and management. Pediatr Dermatol. 2014;31(1):1-7. https://doi.org/10.1111/ pde. 12245 